\title{
Transformation of the Military in the 21st Century: The Lithuanian Case
}

\begin{abstract}
The article aims to reveal how the changing international environment, Lithuania's membership in NATO and the reform of its National Defense System influence the development of the Lithuanian military and to what extent the latter corresponds to the general trends in the development of the militaries in NATO countries. In the first part, the Charles C. Moscos model of the transformation of the society and the military from modern to postmodern which is applied in the comparative analysis of the development of the armed forces in Western democracies is presented. This part deals with the trends in changes of the armed forces of NATO countries in the period after the Cold War and collapse of the communist system. In the second part of the article, variables of the Moscos model are used as a theoretical basis to discuss the trends in the changes of the Lithuanian military. Attempts are also made to determine the extent to which the changes in the Lithuanian armed forces correspond to similar processes in the old NATO countries and what problems Lithuania faces having become a member of NATO.
\end{abstract}

\section{Introduction}

With the collapse of the socialist system and the end of the Cold War, there were quite a few considerations regarding the changing nature of conflicts and wars in the present-day world. Issues related to the transformation of the military of democratic states received particular attention. After the decade following the "velvet" revolutions, members of the Inter-University Seminar on Armed Forces and Society (IUS) stated that "studies of armed forces are enjoying unprecedented renaissance"1 . The statement was inspired by both theoretical discussions about radical changes in international relations and the role of the military in the world after the fall of the Iron Curtain and processes of technological, organizational, social and political changes within armed forces.

\footnotetext{
"Dr. Jürate Novagrockiené - Professor of the Department of Political Sciences of the General Jonas Žemaitis Military Academy of Lithuania, Director of the Strategic Research Center. Address: Šilo 5A, Vilnius, tel. 852103571, e-mail: jurate.novagrockiene@lka.lt

${ }^{1}$ Moscos C.C., Williams J.A., Segal D.R., eds., The Postmodern Military, N.Y., Oxford University

Press, 2000, p. ix.
} 
As far back as Michail Gorbachev's leadership, heated discussions in which "the orthodox security concept emphasizing territorial integrity and political independence of states, the shifting balance of power between East and West, and the military problems of defense, deterrence and arms control" ${ }^{2}$ gave way to new attitudes towards international relations and security and defense policy. These attitudes rested on a far broader conception of security ${ }^{3}$ and did not confine to a merely political-military dimension, but replaced the categories of conflict and violence with the principle of cooperation with former adversaries, projecting security onto the individual as well.

With changes in interpretations of security and new threats, the conception of their management strategy also changed. This was reflected both in shaping security and defense policy and reforming one of its implementation tools, that is, armed forces. In transition from total territorial and unconditional defense to collective defense, as far back as the 90 -s of the $20^{\text {th }}$ century, some of NATO states in Europe renounced compulsory military service ${ }^{4}$, whereas others are planning to renounce it or are downsizing the number of conscripts in the $\mathrm{army}^{5}$.

However, whether to maintain compulsory military service or totally renounce it is only one of the aspects of the transformation of contemporary armed forces. Comparative research of the 50 -s of the $20^{\text {th }}$ century gradually revealed that military forces were a constantly changing institution responsive to changes in the internal and international environment. Research into the armed forces of NATO states and, primarily the USA, carried out during the last decade led to the theoretical assumption that the years 1989-1990 were a dividing line between the modern and postmodern military ${ }^{6}$. According to many military sociologists, as institutions, contemporary armed forces of Western countries face such problems as newly perceived military missions, structural changes, human resources, distribution of funds, professional change, relations with the society, etc. and require a thorough analysis?.

These years marked the beginning of the transformation of the militaries of postcommunist countries which was much more complicated due to the processes of

\footnotetext{
${ }^{2}$ Averre D., Cottey A. "Introduction: Thinking about Security in Postcommunist Europe" in Averre D., Cottey A., eds, New Security Challenges in Postcommunist Europe. Securing Europe's East, Manchester: Manchester University Press, 2002, p. 2.

${ }^{3}$ See: Snyder C.A., ed., Contemporary Security and Strategy, London: Macmillan Press, 1999; Buzan B., People, States and Fear. International Security Studies after the Cold War, Vilnius: Eugrimas, 1997.

${ }^{4}$ Belgium in 1992, the Netherlands in 1993, France in 1996. See: Haltiner K.W. "Mass armies in Western Europe" in Vlachova M., ed., The European Military in Transition, Baden-Baden: Nomos Verlagsgesellschaft, 1998. In the United Kingdom compulsory military service was introduced only in 1916-1919 and 1939-1960. See: Parrot A., "Professional Armed Forces: Experience of the British Army" . See: Novagrockienė J., edProfessional Army: Experience of Western Countries and Perspectives in Lithuania, Vilnius: The General Jonas Žemaitis Military Academy of Lithuania, 2005. (in Lithuanian).

${ }^{5}$ Ibidem.

${ }^{6}$ Williams J. A. "The Postmodern Military Reconsidered" in Moscos C.C., Williams J.A., Segal D.R., eds., The Postmodern Military, N.Y., Oxford: Oxford University Press, 2000, p. 273.

${ }^{7}$ Moscos C.C., "Armed Forces After the Cold War" in Moscos C.C., Williams J.A., Segal D.R., eds., The Postmodern Military, N.Y. Oxford: Oxford University Press, 2000.
} 
democratization of the political regime and transition from planned to market economy as well as due to the soviet legacy. The majority of Central European countries inherited huge poorly equiped armies whose maintenance and restructuring required political will and enormous financial costs.

Unlike the armed forces of other Central-Eastern European countries, the armed forces of Lithuania, Latvia, Estonia, Slovenia, and Macedonia were built from scratch. In the case of Lithuania, the need to restore the army was predetermined by the legacy of the dependence on the Soviet Union as well as the political situation after the restoration of the independence of Lithuania. The Soviet Army had been an occupation army and after the withdrawal of its last units in 1993, the developing armed forces of Lithuania faced such problems as the formation of the national defense system, the need of human resources for the developing Lithuanian military, protection of facilities and armaments that had been taken over from the Soviet Army, financing, etc.

Restoration of the Lithuanian military and its adjustment to security and defense policy of the country were particularly dynamic. In slightly more than a decade the National Defense System got rid of the Soviet legacy, reformed the organizational structure, developed and established the mechanism of democratic civil control of the armed forces, renewed the officer corps ${ }^{8}$. However, qualitative changes in the Lithuanian military began only in 2003 when, having received an invitation to become a member of NATO, Lithuania started the reform of the National Defense System (NDS). Despite the rapid development of the national armed forces, research of these processes still remains at the initial stage ${ }^{9}$.

The present article has a twofold purpose. Firstly, it provides a review of theoretical discussions about changes in the contemporary military in reference to military sociology, and attempts to prove that the model of the transformation to the postmodern military can be applied as a theoretical basis in the analysis of the armed forces of post-communist countries.

Secondly, attempts are made to explore to what extent changes in the Lithuanian armed forces influenced by external and internal factors correspond to hypothetical trends in the transformation of NATO militaries and to identify the problems and challenges that the armed forces of Lithuania face after the country became a member of NATO and the European Union.

\footnotetext{
${ }^{8}$ Norgèla J., "Lithuania's Accession to NATO and the Professional Army". See: Novagrockienè J., ed., Professional Army: Experience of Western Countries and Perspectives in Lithuania, Vilnius: The General Jonas Žemaitis Military Academy of Lithuania, 2005. (in Lithuanian).

${ }^{9}$ Urbelis V., Urbonas T., "The Challenges of Civil-Military Relations and Democratic Control of Armed Forces: the Case of Lithuania" in Cottey A., Edmunds T., Forster A., eds., Democratic Control of the Military in Postcommunist Europe, Houndmills: Palgrave Publishers Ltd, 2002, p. 108-125; Gricius A.,Paulauskas K., "Democratic Civil Control of the Armed Forces in Lithuania". See: Lithuanian Strategic Annual Review 2002, Vilnius: The General Jonas Žemaitis Military Academy of Lithuania, 2003; Novagrockienè J., ed., Professional Army: Experience of Western Countries and Perspectives in Lithuania, Vilnius: The General Jonas Žemaitis Military Academy of Lithuania, 2005. (in Lithuanian).
} 


\section{Armed forces in the postmodern era: theoretical assumptions}

For over a decade military sociologists have been investigating changes in the military after the Cold War in the countries of democracy. Similarly to the majority of scientists of this period, they failed to avoid the euphoria caused by the collapse of the socialist system.

At the $12^{\text {th }}$ World Congress of Sociologists held in Madrid in 1990, Charles Moscos, somewhat confirming Francis Fukuyama's thesis about the end of history ${ }^{10}$, formulated the hypothesis that modern states evolve from war readiness societies to war deterrence societies, while recently they have been transforming into warless societies and, correspondingly, changed their war sociology ${ }^{1}$. He argued that war as a means of conflict management has become less likely between Europe and the great states of the world; therefore, the relationship between the society and the military and, consequently, the nature of the military, are changing. The Congress raised the idea that at present peace rather than war sociology should be discussed.

Moscos tried to create a systemic model to the comparative war sociology: "Our concern is to grasp the whole, to place the salient fact, and to have a framework to appraise the emergent armed forces" 12 . He suggested three types of the development of the society and the military - war readiness, war deterrence and warless societies which, as analytical ideal types, could be applied in studying the militaries of Western democracies.

According to the suggested types, NATO and Warsaw Pact countries of the $50-\mathrm{s}$ and 60 -s of the $20^{\text {th }}$ century possessing large standing forces, usually consisting of conscripts, corresponded to war readiness societies.

The USA, Canada and Great Britain of the 60-70-s corresponded to war deterrence societies, whereas, according to the author, nearly all NATO countries and the Soviet Union possessed certain analogous features. This type of armed forces can be characterized by transition from mass to well-paid professional and technical armies.

At that time, Western and North Atlantic countries, such as Sweden, Switzerland, Canada and "even the USA" ${ }^{13}$, whose armed forces were restructured from mass to small regular forces backed by the reserve ${ }^{14}$, corresponded to warless societies.

${ }^{10}$ Fukuyama F., "The End of History?", National Interest, 1989. Summer.,

${ }^{11}$ Moscos C. C., "Armed Forces in a Warless Society”, Forum 13, Munich, 1992, p. 4.

${ }^{12}$ Ibidem.

${ }^{13}$ During the years of the Cold War the USA had the biggest professional $(2.6 \mathrm{mln})$ and best armed forces in NATO.

${ }^{14} \operatorname{Moscos}($ note 11), 6. 
Table1. Armed Forces and Society"

\begin{tabular}{|l|l|l|l|}
\hline $\begin{array}{l}\text { Armed Forces } \\
\text { variable }\end{array}$ & War Readiness & War Deterrence & Warless \\
\hline $\begin{array}{l}\text { 1.Formal } \\
\text { Organization }\end{array}$ & Mass army & Professional army & Cadre and rezerve force \\
\hline $\begin{array}{l}\text { 2.Majot Item in } \\
\text { Personnel Budget }\end{array}$ & $\begin{array}{l}\text { Agregate personnel } \\
\text { costs }\end{array}$ & Per capita personnel costs & Rezerve infrastructure \\
\hline $\begin{array}{l}\text { 3.Major Item in } \\
\text { Weapons Budget }\end{array}$ & $\begin{array}{l}\text { Low-technology } \\
\text { weapons }\end{array}$ & High-technology weapons & $\begin{array}{l}\text { Low-and } \\
\text { technology wpn. }\end{array}$ \\
\hline $\begin{array}{l}\text { 4. Membership } \\
\text { Indentification }\end{array}$ & Institutional & Professional & Civic \\
\hline $\begin{array}{l}\text { 5. Organizational } \\
\text { Tension }\end{array}$ & Service roles & Budget fights & Mission substitution \\
\hline $\begin{array}{l}\text { 6.Conscienious } \\
\text { Objection }\end{array}$ & Limited or prohibited & Permited on routine basis & $\begin{array}{l}\text { Subsumed in alternative } \\
\text { civilian sv. }\end{array}$ \\
\hline $\begin{array}{l}\text { 7.Recruitment } \\
\text { Representative of male }\end{array}$ & Stratified per labor market & $\begin{array}{l}\text { Represent. .of } \\
\text { adults } \\
\text { (military+civilian) }\end{array}$ \\
\hline $\begin{array}{l}\text { 8.Dominant Type of } \\
\text { Military Professional }\end{array}$ & Combat leader & Managerial technician & Soldier scholar \\
\hline $\begin{array}{l}\text { 9.Public Attitude } \\
\text { Toward Military }\end{array}$ & Supportive & Apathetic & Skeptical \\
\hline $\begin{array}{l}\text { 10.Military Attitude } \\
\text { Toward Military }\end{array}$ & Hostile & Skeptical & Apathetic \\
\hline
\end{tabular}

"Moscos, C. C., “Armed Forces in a Warless Society”, Forum 13, Munich, 1992, p. 5.

Moscos provided 10 variables, the sum total of which describes three different types of armed forces in respective periods of the development (Table 1). In his opinion, transition of armed forces from one type to another is best reflected by the change of defense expenditures in the analyzed countries. Though the expenditures increased rather than decreased, their structure changed. If in the national defense budget of a war readiness society and war deterrence society a major part of expenditures was allotted to the personnel, in warless societies most finances are planned for training and sustenance of the reserve infrastructure ${ }^{15}$.

Organizational structure and the ratio of servicemen to civilians in armed forces also change. In war societies, the army was a strictly institutionalized hierarchical organization which greatly differed from civil structures, whereas in war deterrence societies, the convergence of military and civil personnel is obvious and "the main battles for the budget" take place in Ministries of Defense, but not between the Army, the Air Force and the Navy. In a warless society the boundaries between the military and civilians are likely to be erased while more civil responsibilities and activities fall onto the military ${ }^{16}$.

However, in 1992, at the seminar "Sociological Projecting of the Future Military", most likely due to the ended euphoria caused by the 1990-1991 Persian Gulf War, Moscos comes up with different terms for the three types: "early Cold War", "late Cold War" and "post-Cold War" societies and armed forces ${ }^{17}$.

${ }^{15}$ Ibidem, p.6-7.

${ }^{16}$ Ibidem.

${ }^{17}$ Ibidem. 
Finally, in 1994, while further improving his concept, Moscos introduces additional variables into the model, such as "threat awareness", "relationship with the media", "the role of the female", "homosexuals in the military", that is, dimensions characteristic of the postmodern society, and creates a newer version of the model (Table 2). This resulted in the appearance of the new categories - "modern", "late modern" and "postmodern" society ${ }^{18}$.

Modern military was completely formed in the $19^{\text {th }}$ century as one of the elements of the establishment of the national state. It consisted of lower-ranking servicemen and the professional officer corps and was manly by its nature and spirit which, regarding its structure and culture, made it greatly different from the civil society. Its origins go back to levee en masse born during the French revolution when the notion of the citizen soldier was coined ${ }^{19}$.

The type of late modern military dominated from the middle of the $20^{\text {th }}$ century to the beginning of the 90 -s and coincided with the period of the Cold War. It is characterized by a mass army with the increasing officer corps professionalism attained at military academies and colleges.

Table2. Armed forces and postmodern society: the USA

\begin{tabular}{|c|c|c|c|}
\hline Armed forces variables & $\begin{array}{l}\text { Modern, } \\
\text { (Pre-cold war), } \\
1990-1945\end{array}$ & $\begin{array}{l}\text { Late Modern, } \\
\text { (Cold War), } \\
1945-1990\end{array}$ & $\begin{array}{l}\text { Postmodern } \\
\text { (Post-Cold War), } \\
1990 \text { - }\end{array}$ \\
\hline 1. Perceived threat & Enemy invasion & Nuclear war & $\begin{array}{lr}\text { Subnational } & \text { (e.g., } \\
\text { ethnic } & \text { violence, } \\
\text { terrorism) } & \end{array}$ \\
\hline 2. Force structure & $\begin{array}{ll}\text { Mass } & \text { army, } \\
\text { conscription } & \end{array}$ & Large professional army & $\begin{array}{l}\text { Small professional } \\
\text { army }\end{array}$ \\
\hline 3. Major mission definition & $\begin{array}{l}\text { Defence of } \\
\text { homeland }\end{array}$ & Support of alliance & $\begin{array}{l}\text { New missions } \\
\text { (peackeeping, } \\
\text { humanitarian) }\end{array}$ \\
\hline $\begin{array}{l}\text { 4. Dominant military } \\
\text { professional }\end{array}$ & Combat leader & Manager or technition & $\begin{array}{l}\text { Soldier-statesmen, } \\
\text { Soldier-scholar }\end{array}$ \\
\hline $\begin{array}{l}\text { 5. Public attitude toward } \\
\text { military }\end{array}$ & Supportive & Ambivalent & Indifferent \\
\hline 6. Media relations & Incorporated & Manipulated & Courted \\
\hline 7. Civilian employees & Minor component & Medium component & Major component \\
\hline 8. Women's role & $\begin{array}{lll}\begin{array}{l}\text { Separate corps or } \\
\text { excluded }\end{array} & & \\
\end{array}$ & Partial integration & Full integration \\
\hline $\begin{array}{l}\text { 9. Spouse and military } \\
\text { community }\end{array}$ & Integral part & Partial involvement & Removed \\
\hline $\begin{array}{l}\text { 10. Homosexuals in the } \\
\text { military }\end{array}$ & Punished & Discharged & Accepted \\
\hline $\begin{array}{l}\text { 11. Consciencious } \\
\text { objection }\end{array}$ & $\begin{array}{l}\text { Limited } \\
\text { prohibited }\end{array}$ & Permited or rutine basis & $\begin{array}{l}\text { Subsumed under } \\
\text { cvivilian service }\end{array}$ \\
\hline
\end{tabular}

*Moscos C. C., "Toward a Postmodern Military: The United States as a Paradigm" in Moscos C. C., Wiliams J.A., Segal D. R., eds., The Postmodern Military, N.Y., Oxford: Oxford University Press, 2000, p. 15.

${ }^{18}$ Nuciari M., "Models and Explanations for military Organizations: An Updated Reconsideration" in Caforio G., ed., Handbook of the Sociology in the Military. N.Y.: Kluwer Academic/Plenum Publishers, 2003.

${ }^{19}$ Moscos, (note 7), p. 1. 
The postmodern type is characteristic of the present period. The collapse of communism in the Soviet Union and Eastern Europe gave impetus to changes in armed forces. In the absence of threat of invasion, Western states no longer needed to retain such militaries whose social values essentially differed from the majority of the society. "Although national patriotism continues to be emphasized by the armed forces, globalization of finances, trade, communications and other vital human activity undermine the traditional foundation of national sovereignty" 20 .

In his attempts to conceptualize the research of the development of the armed forces in the $21^{\text {st }}$ century, Moscos uses the experience of the USA as the main paradigm for ideal postmodern military. However, as the author himself asserts, the postmodern military is an ideal type which, via many variables, enables to identify the main trends distinguishing between modern, late modern and postmodern armed forces $^{21}$. Nevertheless, in his opinion, the universality of the model is limited to the analysis of the militaries of developed Western democracies.

11 variables of the new version of the model (Table 2) are logically interconnected. According to Moscos, the first variable - threats and their awareness - is undergoing historical changes. Before the Cold War, there were fears of an attack against the state; therefore, a mass army was necessary. In the years of the Cold War, with the threat of the nuclear weapon and improvement of military equipment, a need for technically well- trained military professionals arose. Recently, new threats - local wars and terrorism - have emerged. Respectively, defense policy has undergone changes wherein territorial defense was replaced with collective defense, in essence, changing the conception of the military mission.

The new missions mark a fundamental change in the objective of the militaryfrom the defender of the state it turned into a participant of peacekeeping and humanitarian missions. This gave rise to discussions in the USA military about the extent to which "operations other than war" decrease the development of "the warior's" abilities ${ }^{22}$.

The composition of the personnel changed respectively: in 1973, the USA renounced conscription and reduced the number of the personnel and the budget. After the Vietnam War and particularly at the end of the Cold War, reserve forces became an integral part of the armed forces ${ }^{23}$.

The profession of the serviceman also changed. Before the Cold War, art of war and leadership were the basic requirements; however, technological sophistication eliminated violence as the essential component of the victory. In modern times the platoon commander was replaced with the specialist-leader. New professions, such as an officer-scientist and officer-diplomat emerge in the postmodern society.

Summarizing the Moscos model, John Allen Williams claimed that it is a social sciences model oriented towards the West, or rather, towards America, and it is possible that a Western oriented model would miss important elements of interaction if used in where its assumption do not apply. It could be even argued that using of nonindegenous model to explain variations in particular social system is a form of intellectual imperialism" 24 .

\footnotetext{
${ }^{20}$ Ibidem, p. 2.

${ }^{21}$ Moscos Ch. C., "Toward a Postmodern Military: The United States as a Paradigm" in Moscos Ch.

C., Williams J. A., Segal D.R., eds., The Postmodern Military, N.Y., Oxford University Press, 2000,

p. 14.

${ }^{22}$ Ibidem, p.17.

${ }^{23}$ Ibidem, p. 18.

${ }^{24}$ Williams (note 6), p. 272.
} 
Nevertheless, based on this hypothetical model, among the countries analyzed in the publication The Postmodern Military, the development of the military of South Africa is discussed, which raises doubts about the rather strict standpoint held by Williams.

In fact, a methodological question arises whether the same theoretical models are applicable in the analysis of similar processes in the new NATO countries. It is obvious that both transformation processes in NATO armed forces and their problems are to a lesser or greater extent characteristic of postcommunist NATO members (including Lithuania).

On the other hand, there is no doubt that armed forces of postcommunist countries lag far behind the old NATO states; the specific problems they encounter in the process of the reform are closely related to universal problems which are, in one way or another, typical to the armed forces of all NATO states. Therefore, in this article the variables of both the first and the second model are used as the criteria for the analysis of the changes in the Lithuanian military.

It should be noted that in the second part of the article attempts are made not to analyze the technical aspect of the reform process, but rather to reveal how much its implementation conforms to the general trends in NATO armed forces and what challenges the membership in the Alliance poses.

The reform of the armed forces and its context are primarily analyzed by using variables of the postmodern military (Table 2) with the exception of "the spouse integration" variable; variables of the first model are applied which were rejected in the later variant, i. e. "the main articles in the budget", "the main articles in the defense budget" (Table 1 ).

\section{Reform of the Lithuanian Armed Forces: towards the postmodern military?}

In November 2002, at the meeting of Heads of State of NATO countries, held in Prague, alongside a group of other Middle and Eastern European countries, Lithuania was invited to join the Alliance. The guaranteed membership in the Alliance gave impetus to working out political, legal, financial and technical prerequisites for the NDS reform prior to the formalization of the new status of the country ${ }^{25}$.

The planning of the reform was primarily based on the revision of defense policy and military strategy of Lithuania. If before the Prague Summit, one of the strategic goals of Lithuania had been total and unconditional defense, so at the beginning of 2004, the principle of collective defense was emphasized and on 15 November of the same year it was established in the adopted "Military Strategy of the Republic of Lithuania" (further -Strategy). The Strategy states that there is no direct military threat to Lithuania, however, "in the closest security environment of Lithuania there still are countries that have not completely established democratic constitutional system and which maintain relatively huge military capabilities; therefore, a probability of the occurrence of military threats still remains" ${ }^{26}$. For this reason, the

${ }^{25}$ Lithuania's membership in NATO ratification documents were submitted on 29 March 2004.

26 "The Military Strategy of the Republic of Lithuania", http://www.kam.lt/index.php?ItemId=29340.

7 December 2004. 
principle of persuasive defense and deterrence remained in the document. In the appraisal of threats, the Strategy emphasizes the growing interdependence between different countries and regions, that is why non-military threats, such as international terrorism, organized crime, illegal trade in arms, drugs and people, uncontrolled migration, spread of dangerous diseases, danger of unconventional threats and international terrorism, are becoming of growing importance.

\subsection{Threat perception as impetus for change}

"Threat perception", the first variable of the Moscos model of the transformation of the military in the postmodern era, corresponds to the interaction between threats and security and defense policy and suggests that from the viewpoint of perspective the trends in the development of the Lithuanian armed forces do not significantly differ from the trends in the old democracies. However, the time when the turning point in security and defense policy was politically implemented obviously differs from the time fixed in Western countries -1989-1990.

On the one hand, restoration of the Lithuanian armed forces basically ended only in 1995 . On the other hand, before 1999, a traditional concept of security prevailed where the guarantee of political-military security of the country was the key objective of foreign policy ${ }^{27}$. The formation of the armed forces of Lithuania was based on it.

Gradual transition to the new strategy is provided in the publications "The White Book" of 2000, "The National Security Strategy" of 2002 and "The Program of the Government of the Republic of Lithuania for 2001-2004" and other documents identifying a broad spectrum of threats ranging from international terrorism to uncontrolled migration, including social and economic threats ${ }^{28}$, although these formulations have not been turned into defense policy practice.

Like in many European states, politically revised and legally established contemporary security and defense policy of Lithuania founded on a broader concept of security threats was influenced by external factors. Only having become a member of NATO, Lithuania was determined to change its fundamental concepts of defense policy.

From the retrospective point of view, the total and unconditional defense principle was relied upon too long and the army was formed with the orientation towards territorial defense due to the lack of political will and, most likely, to the interest of the military command of the armed forces to maintain the existing format of the military, because greater numbers of conscripts meant more jobs for professional military personnel and, consequently, fewer social problems. Thus, not so much the awareness of threats as their transformation into the security and defense policy dimension made an impact on the change of the structure of the military.

${ }^{27}$ Nekrašas E., „NATO ir Europos Sajungos santykių transformacija ir Lietuvos užsienio politika"(Transformation of the Relations between NATO and the European Union and Foreign Policy of Lithuania ") in Šiauress Atlanto erdve ir Lietuva (North Atlantic Space and Lithuania), Vilnius: Eugrimas, 2001, p. 17 (in Lithuanian).

${ }^{28}$ Nacionalinio saugumo strategija. Patvirtinta Lietuvos Resppublikos Seimo 2002 gegužès 28 d. Oficialus Lietuvos Respublikos leidinys (The National Security Strategy. Approved by the Seimas of the Republic of Lithuania on 28 May 2002. An official publication of the Republic of Lithuania), Vilnius: The Ministry of National Defense, 2002, p. 7-9 (in Lithuanian). 


\subsection{Change of the structure of the armed forces}

After the invitation, consultations with NATO on the commitments of Lithuania, as a member of the Alliance, began. The recommendations and remarks suggested that Lithuania should build smaller but more capable and easily deployable military units, modernize its armaments in order to more actively participate in both the collective defense system and peacekeeping operations.

The NDS reform begun in 2001, gained new impetus in 2003. For the first time, "The Guidelines for the Development of the National Defense System in 2004$2009 " 29$ were prepared and adopted not for the usual three-year period, but for a sixyear planning cycle used in NATO countries. Specific measures for the restructuring of the armed forces were provided for in the Guidelines: by 2008, to downsize the armed forces approximately twofold and form one fully equipped rapid reaction brigade, by the beginning of 2005 , to train one battalion completely meeting the Alliance requirements for participation in international operations ${ }^{30}$.

In 2003, Lithuania had mixed armed forces with professional servicemen prevailing. There were 7,950 military personnel in the Army, 3,027 of which were conscripts, 650 served in the Navy (130 conscripts) and 1,150 served in the Air Force (150 conscripts). 63 per cent of the Lithuanian Armed Forces were professional servicemen and 37 per cent conscripts ${ }^{31}$. Reduction of the number of conscripts in the armed forces was planned and the limits were set: in $2003-4,500$, in $2004-$ 3,681 , in 2005 - up to $3,500^{32}$. In other words, by the year 2008, the number of both professional servicemen and conscripts is planned to be reduced by half, i. e. it should constitute less than 18 per cent of the total personnel of the armed forces.

A qualitative reorganization of military structures based on calculations made by both NATO experts and Lithuanian specialists has also been provided for in the Guidelines. New tasks for the armed forces are being designed, the emphasized increase of capabilities calls for the reform of the military training system in order to make study programs compatible with the new plans of the military and execution of collective defense tasks, specialization in the areas where, according to the resources available, capabilities necessary for collective defense could be built ${ }^{33}$. Territorial defense units are also being reduced and reformed adjusting them to the protection of civil strategic objects and the needs of civil authorities.

In developing military capabilities of Lithuania, priority is given to the Land Forces that have been the strongest link of the armed forces since the very beginning of their restoration. It is also planned to retain the Air Force and the Naval Force,

\footnotetext{
${ }^{29}$ „Karšto apsaugos sistemos gairès 2004-2009 metams” ( "The Guidelines for the Development of the National Defense System in 2004-2009"), http://www.kam.lt/index.php?ItemId=30319, 15 May 2004 (in Lithuanian).

${ }^{30}$ Ibidem.

${ }^{31}$ Lithuania, http://www.nato.int/invitees2004/lithuania/defence.htm, 25 August 2004.

${ }^{32}$ Lietuvos Respublikos Vyriausybe, Nutarimas dèl Lietuvos Respublikos Vyriausybès 2004 metu veiklos atskaitos pateikimo Lietuvos Respublikos Seimui (The Government of the Republic of Lithuania, The Decision on Rendering the Account of the Activity of the Government of the Republic of Lithuania in 2004 to the Seimas of the Republic of Lithuania), 30 March 2005. No 337, http:/ /www.lrv.lt/13_vyr_dok/n0337.pdf, 21 May 2005 (in Lithuanian).

${ }^{33}$ Ibidem
} 
though small in size, because capabilities of these branches of the armed forces are important for securing territorial integrity and carrying out missions of the Alliance.

The essential element of the Land Forces, the Standby High Readiness Brigade "The Iron Wolf", must be trained for broad-spectrum operations outside Lithuania by 2008, whereas by the end of 2004, the Algirdas battalion is to be manned by professional military personnel and trained to conduct operations outside Lithuania in conjunction with NATO forces ${ }^{34}$.

Units of the National Defense Volunteer Forces (NDVF) are being downsized. The active reserve of the NDVF volunteers is to be cut to 4,200 men and the number of professional military personnel to 800 . By 2008, NDVF must be trained to accept reinforcements of allies, execute protection of strategic state objects, render assistance to civil authorities in case of disasters, cooperate with the police in face of the threat of terrorist acts, etc ${ }^{35}$.

Though NATO does not point out what military its members should retain, alongside increased requirements for the growth of capabilities and interoperability with NATO forces, need for well-trained personnel, capable of mastering sophisticated modern equipment, is also objectively growing.

J. Petrauskaite, who analyzed the impact of the revolution in the military affairs on the development of the armed forces of Lithuania, points out that "political analysts maintain that, in the $21^{\text {st }}$ century, low intensity conflicts (LIC) or conflicts close to war will pose a standing threat. The military designated to fight against these threats will be different from that for high intensity conflicts (HIC) ${ }^{36}$. Since the key requirements for the military of Lithuania are collective defense and participation in broad-spectrum operations, it must have the most modern armaments and equipment while training of military personnel must guarantee their ability to operate such armaments ${ }^{37}$. Technology is another factor that objectively strengthens the trend of the professionalization of the military and this, in further perspective, can lead to a complete renunciation or a temporary suspension of the compulsory military service.

Though changes in the structure of the Lithuanian armed forces have just begun, it is obvious that they coincide with analogous processes in the militaries of NATO countries. Yet, the downsizing of the military and professionalization also increase social problems.

With the decreasing need for conscripts, it is planned, in the further perspective, to call young people for the compulsory military service on a voluntary basis. The institution of conscripts is rather important in Lithuania since it also helps solve social problems: civil development, unemployment, professional orientation. According to the research of the army conducted by the Strategic Research Center of the Lithuanian Military Academy since 2002, conscripts predominantly come from the population of small towns and villages, earnings per capita of half of military person-

\footnotetext{
${ }^{34}$ „Karšto apsaugos sistemos gairès 2004-2009 metams” ("The Guidelines for the National Defense System for 2004-2009”), (note 29).

${ }^{35}$ Ibidem.

${ }^{36}$ Petrauskaite J., „Revoliucija karinëje srityje: įtaka Lietuvos kariuomenès profesionalizacijai?“ ("Revolution in the Military Affairs: Impact on the Professionalization of the Lithuanian Military?") See: Novagrockiene, (note 2) p. 82 (in Lithuanian).

${ }^{37}$ Ibidem, p. 89.
} 
nel families constitute only 400 litas per month, every fifth soldier was unemployed before the call up, slightly over 50 per cent of them had secondary education ${ }^{38}$.

Besides, the reform in the military also determines different social problems. Because of the necessity to downsize personnel and retire a greater number of servicemen than it used to be customary, the reintegration of military personnel into civil professions and institutions has become more challenging.

Also, the National Defense System constantly experiences financing problems. Though on 23 May 2001 parliamentary parties signed an agreement on defense policy for 2001-2004, confirming the commitment of the parties to develop the National Security and Defense System of the State as part of the Common European and TransAtlantic Security System and allot the National Defense System 2 per cent of the GDP, but, in fact, only about 1.41 per cent ${ }^{39}$.

Trying to maintain a balance between the necessary capabilities, international commitments and material, human and financial resources available, Lithuania, though supporting defense policy initiatives of the European Union, actually allots a smaller military package to the EU than to NATO and can practically use only forces themselves to guarantee the needs of both organizations.

According to the data of 2003, Lithuania's contribution to the EU had to be "one mechanized and one motorized company as well as a platoon-sized infantry unit, a section of military medics, an engineer platoon, a special forces platoon, one An-26 aircraft, 2 Mi-8 helicopters, 2 minesweepers, two training areas" ${ }^{\prime 4}$. In the future the needs of the EU might grow, but Lithuania's resources are limited; therefore, it is planned, for the time being, to use the same forces to meet the needs of both organizations.

Besides, a unanimous political opinion in reference to the abolition of the compulsory military service is also non-existent. The Social Democrat party tends to retain a mixed-format military, the Liberal and the Center Union would rather support a professional army, The Homeland Union-Lithuanian Conservatives also favor a professional army, but stand for a long-term gradual transition to it ${ }^{41}$. The New Union suggests that drafting to the compulsory military service be renounced and Lithuania limit itself to professional military. Nevertheless, the principle of consistent professionalization of the military is retained.

Though tasks, formulated in the Guidelines, are executed more slowly than it has been planned, it is obvious that the army structure reform changes not only the composition of the personnel, but also encounters challenges of new missions.

\footnotetext{
${ }^{38}$ NovagrockieneJ., Janušauskiene D., Kaminskaite A., Privalomosios tarnybos kariu nuostatos. Ataskaita (Attitudes of the Compulsory Military Service Personnel. Report), Vilnius: The General Jonas Žemaitis Military Academy of Lithuania, 2002, p. 6-11 (in Lithuanian).

${ }^{39}$ Biudžetas (Budget), http://www.kam.lt/index.php?ItemId=33308 05 August 2004

${ }^{40}$ Gricius A., Paulauskas K., "Common Foreign and Security Policy of the EU and Lithuania." See: Lithuanian Annual Strategic Review 2003, Vilnius: The General Jonas Žemaitis Military Academy of Lithuania, 2004, p. 95.

${ }^{41}$ Interview with representatives of parties in carrying out the research "The Attitude of the Lithuanian Population to Security“, 2220. About the research see: Novagrockiene J., Janušauskiene D., "The Attitude of the Lithuanian Population to Security." See: Lithuanian Annual Strategic Review 2002, Vilnius: The General Jonas Žemaitis Military Academy of Lithuania, 2002, p. 277-298.
} 


\subsection{Change of the military mission and professional composition of servicemen}

The most dramatic change within the armed forces relates to the change of their mission, that is, transition from the state defense function to the participation in combined international operations and the collective security system with NATO. Thus, the military of Lithuania has in essence to renounce or at least hold secondary the functional imperative of the late modern armed forces - to fight and defend their state from the enemy. Therefore, at present, the Lithuanian serviceman more often defends and protects people of other countries than his or her citizens. Besides, Lithuania has more often participated in peace operations that do not always call for combat skills, but rather for expertise and communication skills with local population and servicemen of multinational forces, for the capability not to defend but assist. The same applies to the militaries of all NATO countries.

Emergence of new missions is related to a certain identity crisis of the military and the military profession. Alongside combat skills other capabilities must be developed. A serviceman participating in missions must be a rescuer, know the principles of the international law and activity of international organizations, be capable of establishing and maintaining relations with local population, be proficient in foreign languages.

For example, the USA, seeking to retain its characteristic military capabilities, was quick in developing new training tasks and manuals aimed at including the experience gained during the first international operations before the end of the Cold $\mathrm{War}^{42}$.

It is worth noting that a great part of Lithuanian military personnel, serving and living at peace time, consider participation in international missions as a real military life where they are able not only to try their skills and abilities, but also to gain a completely new experience and test themselves ${ }^{43}$. The number of volunteers to participate in international operations usually exceeds the demand.

The Moscos model implies that in the modern and postmodern epoch an officer-fighter is being replaced by an officer-manager, officer-scientist, officer-diplomat. It is obvious that the expanding boundaries of the officer's profession raise new requirements for the training of servicemen.

In preparation for the membership in the Alliance, personnel development was being constantly improved. The data of the year 2000 alone show that 1,000 servicemen and civilian employees of the National Defense System participated in long-term training programs in 22 foreign countries ${ }^{44}$. In 1999-2000, 450 servicemen completed various courses ${ }^{45}$.

In the Guidelines for 2004-2009 it is planned to review the training of military personnel of all categories, focus attention on strengthening of capabilities for trai-

\footnotetext{
42 Moscos (note 21), p. 17.

${ }^{43}$ Maslauskaite A., Novagrockiene J. „Tarptautinėse misijose tarnaujančių karių socialinės prsichologinès problemos" ("Socio-psychological Problems of Military Personnel Serving on International Missions"), Vilnius, The General Jonas Žemaitis Military Academy of Lithuania, 2004 (in Lithuanian).

${ }^{44}$ Professional Improvement, http://www.kam.lt/index.php?ItemId=9475 10 July 2004

${ }^{45}$ Ušackas V., Q\&A Report on Lithuania's Integration into NATO. Washington, May 1, 2002, 5, http://www.ltembassyus.org/pdf/Q_+_A_Report_Lithuania_NATO_Hearing.pdf 04 June 2004
} 
ning senior officers and specialists, continue teaching official NATO languages, expand the International Training Center at the Military Academy of Lithuania, participate in international exercises.

Though the concepts "officer-scientist" and "officer-diplomat" are notyet used in the military rhetoric, the concept "officer-scientist" should rather be related to servicemen who have mastered the fundamentals of scientific activity but not with researchers or officers working on their scientific theses. Beginning with 1994, when the Lithuanian Military Academywas granted the status of a higher educational institution, officers trained here acquire both military and university specialities. It is important that the multi-stage officer training system, comprising the Course for Captains, Master-degree studies, qualification improvement courses at the Baltic Defense College, a possibility to attend international courses, not only imparts and deepens knowledge but also expands the outlook of servicemen.

Diplomatic functions are more often performed by civilian employees of the National Defense System rather than military personnel. Though the military attaché corps is expanding, so far only 10 senior officers perform a diplomatic mission representing Lithuania. Thus, in this respect, Lithuania balances between the late modern and postmodern societies.

\subsection{Key articles of the budget}

In assessing changes in the military, the dynamics of the NDS expenditure structure can be analyzed as a control variable. As it has been mentioned, Moscos states that the main budget quality after the Cold War was a decrease in expenditure for personnel and an increase for procurement.

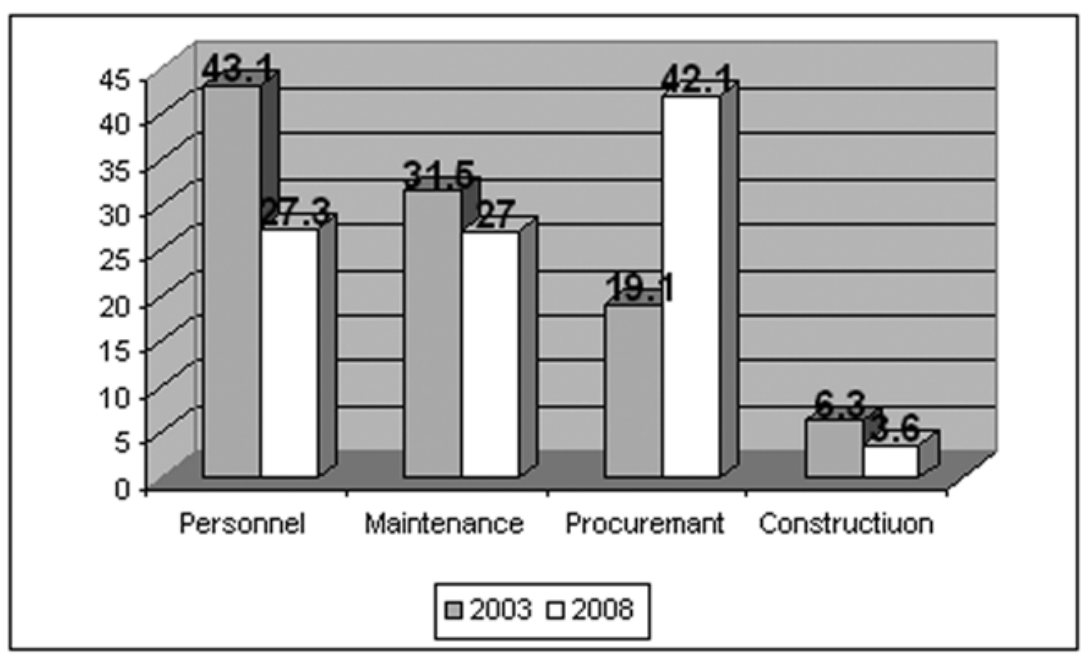

Fig.1. Planned NDS expenditure structure ${ }^{46}$

The Guidelines for the Development in 2004-2009 provide that expenditure for

${ }^{46}$ Report by K.Paulauskas at the Ministry of National Defense on 24 March 2004. 
personnel must not exceed 50 per cent of total NDS expenditure; expenditure for procurement of new armaments, military equipment and materiel including the modernization must be not less than 25 percent; expenditure for infrastructure must not exceed 10 per cent of the total NDS expenditure. Figure 1 indicates that expenditure for personnel is to be cut almost by half, whereas procurement means are to be increased more than twofold ${ }^{47}$.

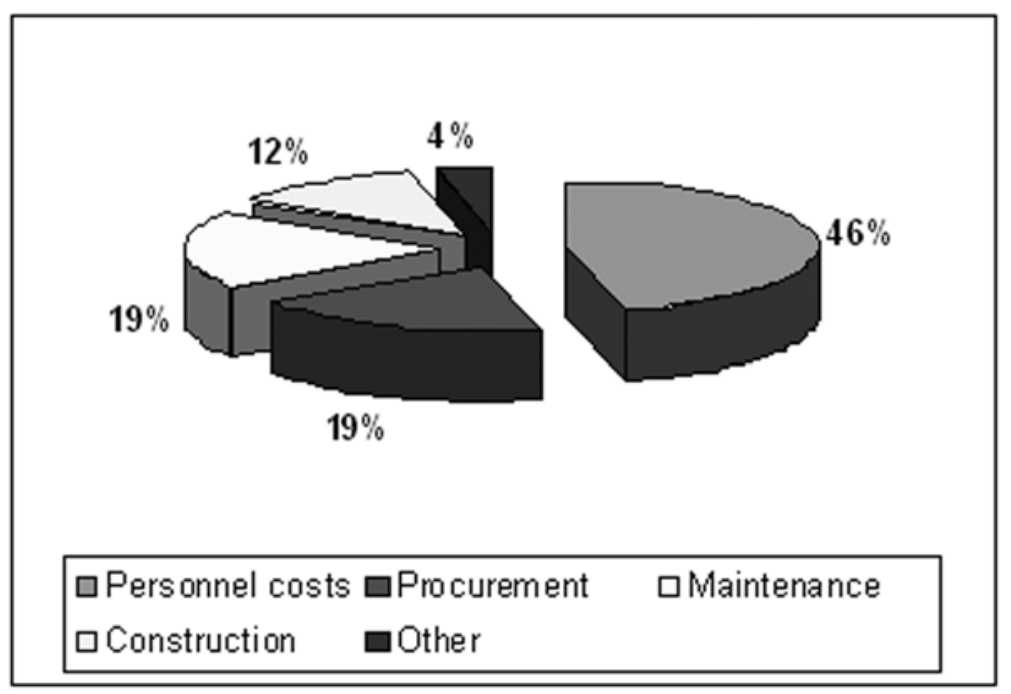

Fig.2. Allocations for the Ministry of National Defense ${ }^{48}$

The NDS budget structure for 2004 only partly confirms the planned trends (Fig. 2). Means allotted for personnel do not exceed 50 per cent, but those for procurement constitute 19.2 per cent of the total NDS budget. Since armaments procurements are generally assigned to the "investments" category, they are not indicated in Fig.2. In 2003, 23.6 per cent of the NDS budget was allotted for investments and armament procurement and in 2004-22.9 per cent ${ }^{49}$.

As far as priorities for armaments and procurement are concerned, it is obvious that realistic acquisitions are planned, taking into consideration a small state budget and reform directions. Special attention is paid to anti-tank, anti-aircraft armaments, transport and logistic supply.

By 2008, it is planned to provide the Land Forces with short-range air defense systems, medium and long-range anti-tank systems, light infantry armaments, and means of tactical communications. The Air Force plans to obtain medium-range air surveillance systems, a short-range air defense system, equipment for surveillance and control system. The Naval Force must update the equipment of territorial sea and exceptional economic zone surveillance system.

In other words, changes in the budget structure and armaments procurement

\footnotetext{
${ }^{47} 2004$ m. išlaidos krašto apsaugai (National Defense Expenditure for 2004), http://www.kam.lt/ index.php?ItemId=33308 06 December 2004

${ }^{48}$ Ibidem.

${ }^{49}$ Ibidem.
} 
confirm the postmodernization trend, though more time is necessary to draw the final conclusion.

\subsection{Public opinion about the military of Lithuania}

Theoretically, in the postmodern society, indifference or even negative attitude towards the military as a structure that is redundant because of the absence of obvious threat, alien and costly, since servicemen are sent to other countries, should grow. Yet in Lithuania, the military is an institution enjoying the highest ratings.

One of the reasons for positive assessment of the military is its fast change and improving image. At present, Lithuanian military does not bear much resemblance to the Soviet army that was infamous for bullying, or the so-called "dedovščina", disorder and corruption. Besides, a great part of the Lithuanian population considered it to be an occupation army and regarded service in its ranks not as a duty to the Homeland but as a coercive military institution.

In public opinion polls, conducted in 2002 and 2003, respondents were asked to indicate to what extent they agree with the statement that contemporary Lithuanian military is completely different from the former Soviet army. Within a year the percentage of respondents that agreed and completely agreed with the statement that the Lithuanian military changed increased from 75 to 85 and the number of those that disagreed decreased from 9 to 6.4 per cent (Fig. 3). The number of respondents that had no opinion on this issue decreased from 15 per cent in 2002 to 12 per cent in 2003.

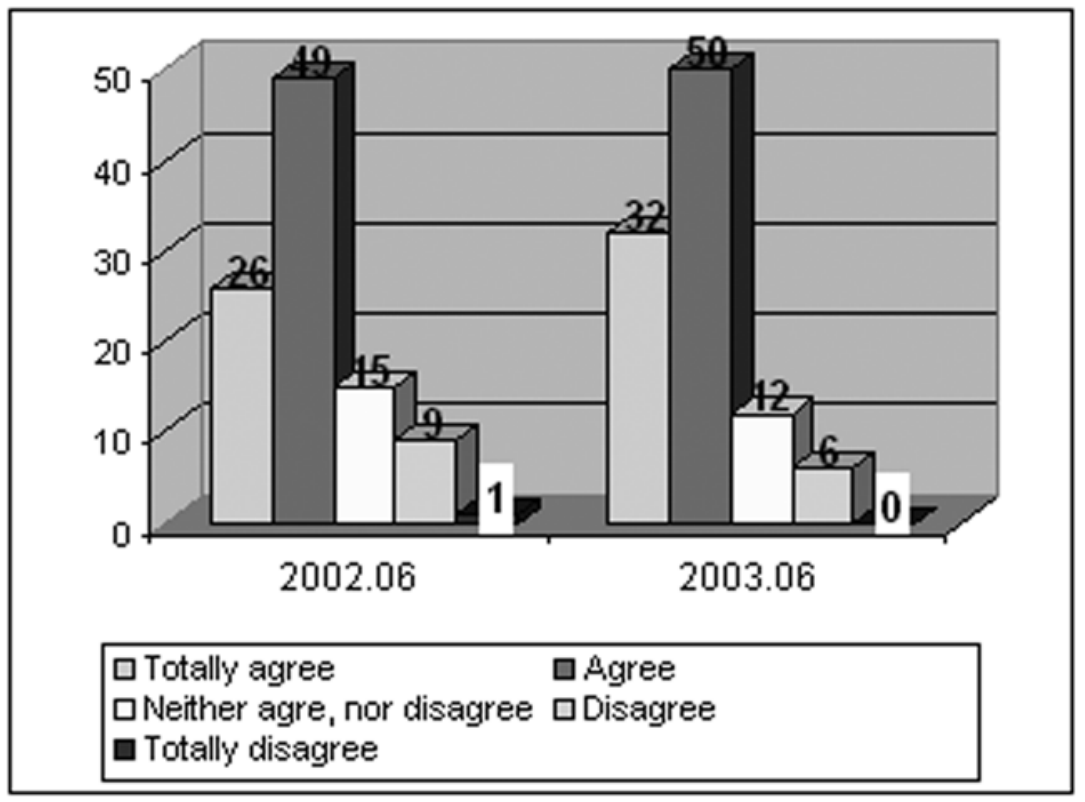

Fig.3. Contemporary Lithuanian military is completely different from the former Soviet army $(\%)$ 
The dynamics of the assessment of Lithuanian military is shown in Table 3. The attitude of the Lithuanian population to the military in 2000-2004 was stable: from 65 to 68 per cent of the Lithuanian population assessed it very positively or positively.

The positive attitude to the military has been determined by historical cultural factors. From the historic point of view, the contemporary Lithuanian military is natural to the country in comparison to the Soviet army. Its restoration is related to the events of 1991, when people, in peaceful protest, opposed the assault by "the Omon", and first volunteers were ready to defend the Seimas. Later, quite a few of them became well-known officers in Lithuania.

Table3. Assessment of the Lithuanian Military in 2002-2004

\begin{tabular}{|l|c|c|c|c|c|}
\hline $\begin{array}{l}\text { How do you asses the present } \\
\text { Lithuanian Army? }\end{array}$ & $\begin{array}{c}\mathbf{0 6 . 2 0 0 2} \\
(\mathbf{\%})\end{array}$ & $\begin{array}{c}\mathbf{0 1 . 2 0 0 3} \\
(\mathbf{\%})\end{array}$ & $\begin{array}{c}\mathbf{0 6 . 2 0 0 3} \\
(\mathbf{\%})\end{array}$ & $\begin{array}{c}\mathbf{1 1 . 2 0 0 3} \\
\text { (\%) }\end{array}$ & $\begin{array}{c}\mathbf{0 6 . 2 0 0 4} \\
(\mathbf{\%})\end{array}$ \\
\hline Very positive & 6 & 7 & 5 & 5 & 6 \\
\hline Positive & 59 & 54 & 61 & 59 & 62 \\
\hline Negative & 18 & 20 & 13 & 15 & 16 \\
\hline Very negative & 2 & 4 & 3 & 2 & 3 \\
\hline Do not know & 15 & 15 & 18 & 18 & 13 \\
\hline
\end{tabular}

Source: Reports on the opinion polls, 2002-2004. Conducted by the Lithuanian-British Market Research and Public Opinion Company “Baltic Surveys Ltd.”, ordered by MoD.

Concluding, the public opinion in case of Lithuania cannot be considered as a criterion of the development of the military into the postmodern type because of specific conditions of its formation and relationship with the society.

\subsection{Mass media and the military}

The relationship of the military and mass media is multifaceted. On the one hand, military institutions usually seek to maintain good relations with journalists. On the other hand, attempts are made to avoid making ad hoc problems of military institutions public because of a possible damage to the image.

Mass media in Lithuania, in reference to the NDS, is internal and external. All NDS newspapers and magazines - Krašto apsauga, Karys, Kardas, Kariūnas - as well as several local newspapers published by certain battalions are attributed to the internal mass media which fulfils the function of both informing and educating the public and the military and also shaping a positive image of the military.

External mass media operates more effectively (dailies) and is bent on seeking for negative rather than positive NDS sides. At the time of peace no censorship is possible, except "self censorship" within the NDS.

During the Cold War period, mass media and the military were like one team, military correspondents had military ranks. In the postmodern society, as Moscos claims, a variant is possible when journalists enjoying technical possibilities outrun the military and inform the public about the events in one or another hot spot of the world faster and more accurately, whereas commanders watch the developments in the activity zone under their control on the commercial CNN television ${ }^{50}$.

${ }^{50} \operatorname{Moscos}$ (note 21), 21. 
The institution of military correspondents in Lithuania is not strong yet and information about the events from hot spots is usually broadcast by journalists of state and commercial television channels. It is possible to state that mass media has a small effect on the public opinion.

\subsection{Women and homosexuals in the military of Lithuania}

The integration of women into the defense sector in many NATO countries started considerably earlier than in Lithuania. Servicewomen emerge due to strengthening feminist movements and are a product of the government sex policy of Western democracies. Yet, a complete integration of women into the military was implemented gradually. For example, in Great Britain, the discrimination of women came legally to be solved only in the 70 -s of the $20^{\text {th }}$ century, but it was only in the 90 -s that women were completely integrated into the military. After the Cold War, they constituted 7.9 per cent of officers and 5.4 per cent of regular soldiers ${ }^{51}$.

In Lithuania, women have been working in the NDS since the beginning of its foundation, however, only in administrative structures. At present, women constitute 52 per cent of civilian employees and 10 per cent of the military personnel, that is 16 per cent of the total NDS employee body ${ }^{52}$. Since 2000, the Military Academy of Lithuania annually admits approximately 9 females $^{53}$. In NATO countries, however, more women serve in military institutions and they are completely integrated into armed forces. Yet, discernible improvements in reference to this criterion make it possible to speak about the transition towards the postmodern military.

However, the attitude towards homosexuals in the military of Lithuania has been predetermined by the fact that the entire society treated them in a rather conservative way. Theoretically, homosexuals have a possibility to choose an alternative military service, but they are not registered, often conceal their identity though some of them do serve in the military. In this respect, the situation in Lithuania will change though very slowly. Therefore, Lithuania is rather a late modern society, and the situation might change only with the changing public attitude.

\section{Conclusions}

Copious empirical studies of the militaries of Western democracies helped reveal new trends and problems regarding changes in military institutions that Charles C. Moscos summarized by constructing a hypothetical model of the transformation of the military from modern into post-modern. Having analyzed the trends in the development of the Lithuanian military according to most criteria of the model, it is possible to state that its variables are suitable to methodologically study changes in the armed forces of Lithuania as well as analyze other postcommunist states.

${ }^{51}$ Dandeker C., "The United Kingdom: The Overstretched Military" in Moscos C. C., Williams J. A., Segal D. R. eds., The Postmodern Military, N.Y., Oxford: Oxford University Press, 2000, p. 40. ${ }^{52}$ Moterys kariuomeneje (Women in the Military), http://www.kam.lt/index.php?ItemId=9473 14 June 2004

${ }^{53}$ Young Females at the Military Academy, http://www.lka.lt/lt/disp.php/lt_cadets/lt_cadets_female 14 June 2004 
Assessing the armed forces of Lithuania within the context of the NDS reform, it is obvious that according to most parameters they are being transformed into the category of the postmodern military. However, alongside this, specific features of Lithuania, determined by historical and cultural factors, are revealed.

Similarly to other NATO states, key factors inducing to review security and defense policy and transform the NDS were external. The turning-point of Lithuanian security and defense policy from the territorial defense to the collective defense was mostly influenced by the membership in NATO and the essential objective - to turn the military of the State, as far as structure, human resources and armaments are concerned, into an organization corresponding to NATO requirements and capable of executing new missions - is primarily subordinated to the Alliance's needs. Therefore, Lithuania's membership in NATO and the European Union implies more commitments and a greater dependence in security and foreign matters on the membership in these organizations.

New military missions, changes in the structure and the military profession testify to the transformation of the Lithuanian armed forces into the postmodern military. Participation of the military in international operations as well as modernization of the armaments within the NDS of Lithuania increase advantages of the professional military service and thus encourage a decrease of the corps of conscripts and the active reserve.

The NDS budget and armaments procurement priorities, though dependent on limited resources, also testify to the new changes.

The number of women within the NDS also indicates that the military is transforming towards the postmodern category. Yet, the society still cherishes rather conservative values according to which the military service is considered to be a masculine activity. Therefore, quite a few problems between the two genders within the military arise. Studies in this area have just begun.

It is likely that the integration of homosexuals into the military is going to be much slower than the integration of women because of the hostile attitude towards them both in the society and the military.

In summary, it is possible to conclude that the military of Lithuania is rapidly moving from the late modern into the postmodern with some remaining features of the former. 